\title{
A New Species of Galendromus (Acari: Phytoseiidae): A Case of Intraspecific Variation and Redefinition of carinulatus Species Group
}

Author(s): Peterson R. Demite, Antonio C. Lofego, Reinaldo J. F. Feres

Source: Annals of the Entomological Society of America, 101(5):804-807. 2008.

Published By: Entomological Society of America

DOI: http://dx.doi.org/10.1603/0013-8746(2008)101[804:ANSOGA]2.0.CO;2

URL: http://www.bioone.org/doi/

full/10.1603/0013-8746\%282008\%29101\%5B804\%3AANSOGA\%5D2.0.CO

$\% 3 \mathrm{~B} 2$

BioOne (www.bioone.org) is a nonprofit, online aggregation of core research in the biological, ecological, and environmental sciences. BioOne provides a sustainable online platform for over 170 journals and books published by nonprofit societies, associations, museums, institutions, and presses.

Your use of this PDF, the BioOne Web site, and all posted and associated content indicates your acceptance of BioOne's Terms of Use, available at www.bioone.org/page/ terms of use.

Usage of BioOne content is strictly limited to personal, educational, and non-commercial use. Commercial inquiries or rights and permissions requests should be directed to the individual publisher as copyright holder. 


\title{
A New Species of Galendromus (Acari: Phytoseiidae): A Case of Intraspecific Variation and Redefinition of carinulatus Species Group
}

\author{
PETERSON R. DEMITE, ${ }^{1}$ ANTONIO C. LOFEGO,${ }^{2}$ AND REINALDO J. F. FERES ${ }^{1,3}$
}

Ann. Entomol. Soc. Am. 101(5): 804-807 (2008)

\begin{abstract}
A new species, Galendromus (Mugidromus) sulamericanus, is described from northwestern São Paulo state, Brazil, and it is included in the carinulatus species group Chant and Yoshida-Shaul, which is herein redefined to accommodate this new species. A variation in the insertion of ZV2 seta in the ventral shield was observed in individuals from the same population. A key is provided for all known species of the subgenus Mugidromus Tuttle and Muma.
\end{abstract}

KEY WORDS Brazil, carinulatus species group, Galendromus (Mugidromus), predatory mites, South America

Galendromus Muma is a genus of Metaseiulini Chant and McMurtry, with 12 species currently known. The majority of the species occur in Central America and in southern USA, but they are also recorded in other parts of the world (Chant and McMurtry 1994). Before this publication, only Galendromus (Galendromus) annectens Muma, was recorded from Brazil (de Moraes et al. 2004).

The genus Galendromus is divided into two subgenera: Galendromus Muma and Mugidromus Tuttle and Muma. The subgenus Mugidromus is separated into two species groups, pinnatus and carinulatus. The species in these groups were reviewed by Chant and Yoshida-Shaul (1984) and included in the subgenus Mugidromus by Chant and McMurtry (1994). The former has two species recorded in North America, whereas the latter species was based on a single species, Galendromus (Mugidromus) carinulatus (DeLeon), described from a holotype female collected on Pithecollobium lanceolatum (HBK.) in La Tinaja, Veracruz, Mexico. In this article, a second species of the carinulatus group, Galendromus (Mugidromus) sulamericanus $\mathrm{n}$. sp., is described and illustrated from specimens collected in northwestern São Paulo state, Brazil.

The locality where those mites were found is a tropical warm and wet area, with dry season that ranges from April to September (with only 15\% of annual precipitation) and wet season that ranges from October to March. The annual precipitation ranges from $\approx 1,100 \mathrm{~mm}$ to $1,250 \mathrm{~mm}$. The annual mean tem-

\footnotetext{
${ }^{1}$ Corresponding author: Programa de Pós-Graduação em Biologia Animal, UNESP-Universidade Estadual Paulista, R. Cristóvão Colombo, 2265, São José do Rio Preto, São Paulo, Brazil (e-mail: peterson_demite@yahoo.com.br).

${ }^{2}$ Departamento de Zoologia e Botânica, UNESP-Universidade Estadual Paulista, São José do Rio Preto, São Paulo, Brazil.

${ }^{3} \mathrm{CNPq}-$ Brazil Researcher
}

perature is $25^{\circ} \mathrm{C}$, with a minimum mean of $20^{\circ} \mathrm{C}$ and maximum mean of $30^{\circ} \mathrm{C}$ (Barcha and Arid 1971, Arid and Barcha 1973).

\section{Materials and Methods}

Dorsal and ventral setal nomenclature are those of Rowell et al. (1978) and Chant and Yoshida-Shaul (1991), respectively. All measurements are given in micrometers. The holotype measurements are shown in bold type followed by the mean and range in parentheses. The type specimens are deposited in the collection of Acari, Departamento de Zoologia e Botânica, Universidade Estadual Paulista (UNESP), São José do Rio Preto, State of São Paulo, Brazil (DZSJRP, http// www.splink.cria.org.br).

\section{Results}

\section{Galendromus (Mugidromus) sulamericanus n. sp.} (Figs. 1-7)

\section{Diagnosis}

This species differs principally from G. (M.) carinulatus by having most setae on central region of dorsal shield slightly serrated; dorsal setae longer, with exception of setae $\mathrm{j} 1, \mathrm{~S} 5$, and $\mathrm{J} 5$ and by the shape of cervix of spermatheca.

\section{Description}

Female (Figs. 1-5) (nine specimens). Dorsum. Dorsal shield 277: 278 (262-297) long, 135: 140 (130-149) wide at level of s4; distinctly reticulated, with strong sclerotization in the dorsocentral area which imparts a ridged appearance; setae: $\mathrm{j} 1$ 12: 13 (11-15), j3 20: 21 $(20-23)$, j4 18: 18 (16-20), j5 15: 16 (15-19), j6 16: 18 

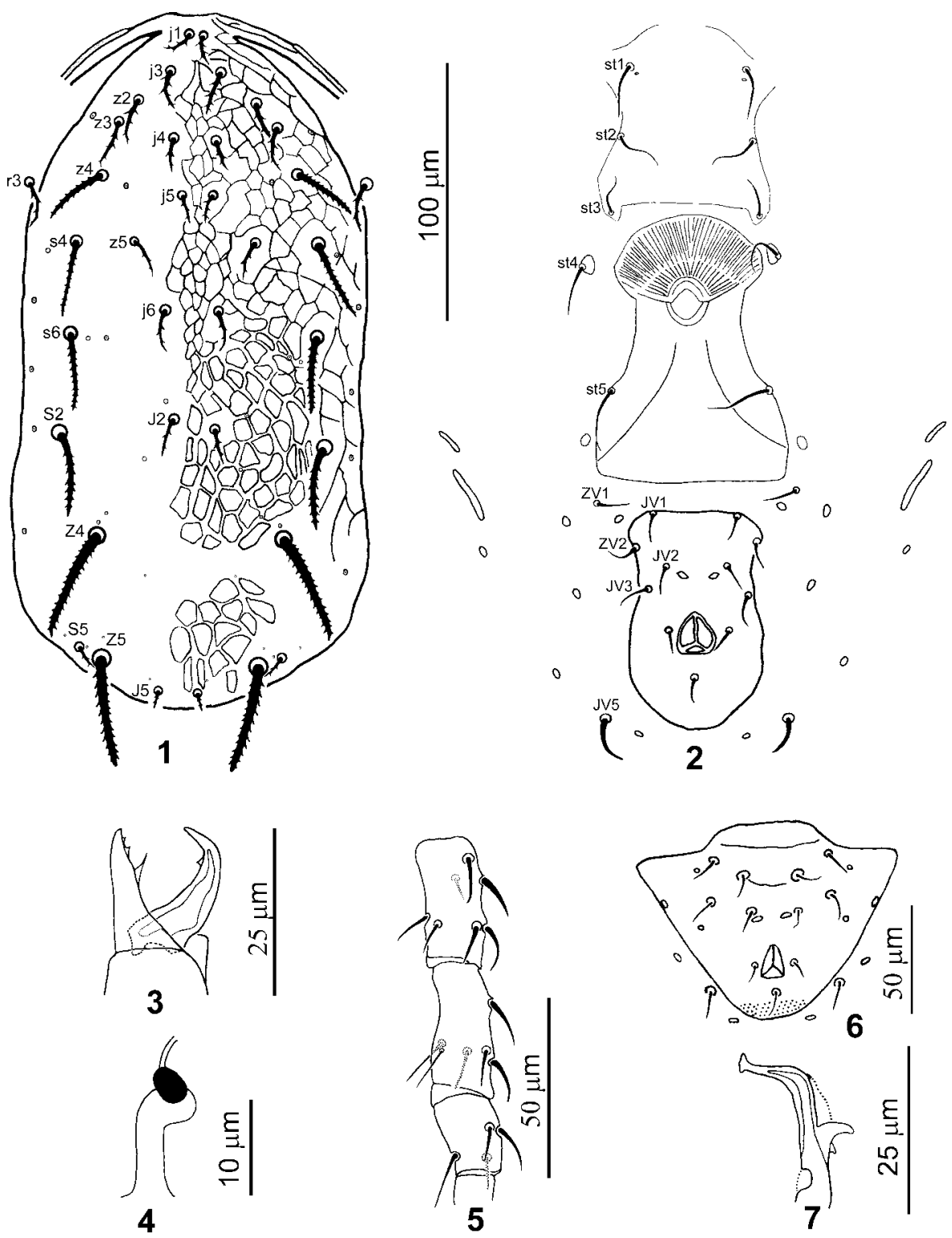

Figs. 1-7. Galendromus (Mugidromus) sulamericanus n. sp. Female: dorsal shield (1), ventral idiosoma (2), chelicera (3), spermatheca (4), and leg IV (genu, tibia, and tarsus) (5). Male: ventri-anal shield (6) and chelicera (7).

(16-20), J2 16: 19 (16-20), J5 7: nine (7-10), z2 22: 21 (19-22), z3 20: 22 (20-23), z4 28: 30 (28-32), z5 16: 18 (16-20), Z4 45: 49 (45-55), Z5 44: 47 (42-56), s4 30: 33 (30-36), s6 33: 36 (33-39), S2 34: 38 (34-42), S5 14: 15 (14-17), r3 22: 21 (19-23).

All setae squamous; z4, s4, s6, S2, and Z5 serrated, and the other slightly serrated.

Peritreme. Extending forward to the level of $\mathrm{j} 3$, but not reaching the level of $\mathrm{j} 1$.

Venter. Sternal shield slightly discernible, with three pairs of setae and with only one visible pair of lyrifissures, posterior to st1; distance between st1-st3 52: 55 (52-57) and between st2-st2 51: 51 (48-54). Genital shield smooth, distance between st5-st5 54: 54
(50-59). Ventri-anal shield smooth; with four pairs of preanal setae and a pair of pores posteriormediad to JV2; 85: 85 (81-89) long, 52: 49 (45-55) wide at level of ZV2, 52: 49 (46-52) wide at level of anus. Setae ZV1 on integument surrounding ventri-anal shield. In some specimens one or both setae of ZV2 pair are on integument surrounding ventri-anal shield. Setae JV5 smooth; 17: 17 (15-19) long.

Chelicera. Movable digit 19: 19 (18-19) with one tooth, fixed digit 20: 20 (19-21) with three teeth.

Spermatheca. Cervix tubular with a bending next to the atrium; 19: 15 (13-19) long.

Legs. Without macrosetae. Chaetotactic formula of genu II: 2-2/0-2/0-1 and genu III : 1-2/1-2/0-1. 

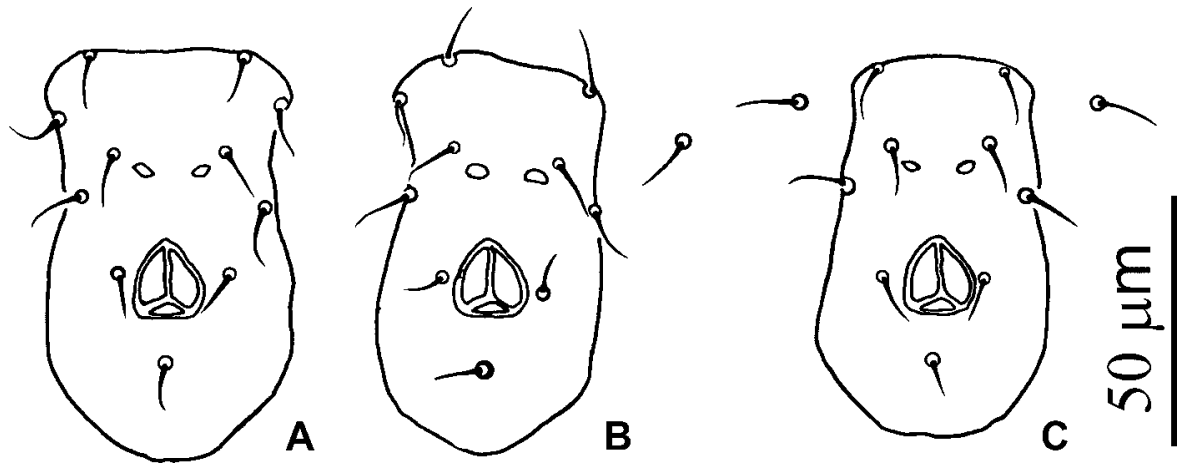

Fig. 8. Variation in the insertion of the ZV2 pair in the venter: holotype (A) and paratypes (B).

Male (Figs. 6 and 7) (two specimens). Dorsum. Dorsal shield 210 (207-212) long, 129 (126-132) wide at level of s4; with reticulation sharp as the female; setae: j1 11 (11), j3 16 (16-17), j4 14 (13-15), j5 13 (12-15), j6 16 (15-18), J2 16 (15-18), J5 eight (7-9), z2 18 (18-19), z4 24 (23-26), z5 17 (16-18), Z4 29 (29), Z5 27 (26-28), s4 27 (27-28), s6 28 (28-29), S2 29 (29), S5 $11(11-12)$, r3 16 (16-17). All setae serrated.

Peritreme. Extending forward to the level of $\mathrm{j} 3$, but not reaching the level of $\mathrm{j} 1$.

Venter. Sternogenital shield smooth; ventri-anal shield subtriangular, mostly smooth, striated from anterior extremity to level of JV1; $82(80-84)$ long and 113 (111-115) wide, with five pairs of preanal setae, one distinct pair of pores posterior and mediad to bases of JV2, and two other smaller pairs of lyrifissures.

Spermadactyl. Shaft 16 (16-17) long.

Legs. Without macrosetae. Chaetotactic formula of genu II and genu III as in females.

\section{Locality and Material Type}

Holotype female, on Xylopia aromatica Lam. Mart. (Annonaceae), 10-II-2007, Nova Granada, State of São Paulo, Brazil, $20^{\circ} 28^{\prime} \mathrm{S} 49^{\circ} 22^{\prime} \mathrm{W}, \mathrm{F}$. M. Nuvoloni coll. Paratypes: four females, two males, same data, locality and collector as the holotype; 1 female, 17-III-2007, same locality as the holotype, V. Russo coll.; one female, 29-VI-2007, same locality as the holotype, V. Russo coll.; two females, 21-V-2002, Barretos, state of São Paulo, Brazil, $20^{\circ} 30^{\prime} \mathrm{S}, 48^{\circ} 34^{\prime}$ W, R. Buosi coll. All paratypes from the same host as the holotype.

\section{Etymology}

The name sulamericanus refers to the continent of South America, because this is the first species of the subgenus Mugidromus recorded in the continent.

\section{Discussion}

Some specimens of Galendromus (M.) sulamericanus $\mathrm{n}$. sp. show a variation in the setae insertion $\mathrm{ZV} 2$ pair in the ventri-anal shield. This variation was observed in specimens from the same population. Six of nine females observed had the pair ZV2 on the ventri-anal shield, two had only one setae of the pair ZV2 in that shield, and one specimen had both setae ZV2 on integument surrounding the ventri-anal shield (Fig. 8).

Muma and Denmark (1962) recorded only three preanal setae on the left side of the ventrianal shield in specimens of Galendromus (Galendromus) annectens (DeLeon), and the presence of three and/or four preanal setae on the ventrianal shield in specimens of G. (G.) occidentalis (Nesbitt). According to Hoy (1985), it is not clear how much of this variation might be genetically determined and how much is due to phenotypic plasticity caused by developmental anomalies.

This new species possesses all of the characteristics of the carinulatus species group, except by having seven setae in genu III instead of six as in G. (M.) carinulatus, and for possessing the setae $\mathrm{z} 4(30 \mu \mathrm{m}), \mathrm{s} 4$ $(33 \mu \mathrm{m}), \mathrm{s} 6(36 \mu \mathrm{m})$, and $\mathrm{S} 2(38 \mu \mathrm{m})$ longer than others on dorsal shield, beyond the setae $\mathrm{Z} 4$ and $\mathrm{Z} 5$. Despite these differences, we believe that the similarities are enough to include this new species in the carinulatus species group. So, we propose a redefinition of carinulatus species group to incorporate the characters of the new species as follows: female idiosoma pattern 12A:6A/JV-4:ZV-3, with 31 pairs of setae; setae z3, s6, J2, S2, S5, JV2, and JV3 present; setae z3, J1, Z1, Z3, S4, R1, JV4, and ZV3 absent; most setae on central region of dorsal shield short, smooth or slightly serrated, whereas on lateral region most setae are longer and strongly serrate; S5 short (14-17 $\mu \mathrm{m})$, inserted closer to Z5 than to Z4; Ge II with seven setae; Ge III with six or seven setae. Other characters as for the subgenus.

This species is the second of the genus Galendromus recorded in Brazil and the first of the subgenus Mugidromus recorded in South America, the known species of this subgenus were recorded in North America (United States and Mexico) (DeLeon 1959, Schuster and Pritchard 1963, Tuttle and Muma 1973, Chant and Yoshida-Shaul 1984.). 


\section{Key to Species of Galendromus (Mugidromus) of the World}

1. Seta ZV3 absent; seta S5 inserted closer to Z5 than to Z4 . . . carinulatus species group (2)

Seta ZV3 present; seta S5 inserted equidistant between $\mathbf{Z 4}$ and Z Z5. . . . . . . . . . . . . . . . . . . . . . . pinnatus species group (3)

2. Setae j4, j5, j6, J2, J5, and z5 slightly serrated. . . . . . . . . . G. (M.) sulamericanus n. sp.

Setae j4, j5, j6, J2, J5, and z5 smooth . . . . . . ............ (M.) carinulatus (DeLeon)

3. Setae $\mathrm{j} 4, \mathrm{j} 5, \mathrm{j} 6$, and $\mathrm{z} 5$ smooth . . . . . . . . ......G. (M.) reticulus (Tuttle and Muma)

Setae $\mathrm{j} 4, \mathrm{j} 5, \mathrm{j} 6$, and $\mathrm{z} 5$ serrated . . . . . . . . ... G. (M.) pinnatus (Schuster and Pritchard)

\section{Acknowledgments}

We thank to Vimael Russo (Progr. Pós-grad. Biologia Animal, UNESP-São José do Rio Preto, São Paulo) and Felipe Micali Nuvoloni (UNESP-São José do Rio Preto, São Paulo), for helping in collecting and mounting the mites. This work was supported by the state of São Paulo Research Foundation (FAPESP) within the BIOTA/FAPESP-The Biodiversity Virtual Institute Program (www.biota.org.br) (1998/7099-0 and 2006/55725-6) and Jovem Pesquisador Program (2006/ 57868-9).

\section{References Cited}

Arid, F. M., and S. F. Barcha. 1973. Água subterrânea na formação Bauru-Região Norte Ocidental do Estado de São Paulo. Bol. Ci. Fac. Fil. Ci. Letr. São José do Rio Preto. 1: $67-101$.
Barcha, S. F., and F. M. Arid. 1971. Estudo da evapotranspiração na região Norte Ocidental do Estado de São Paulo. Revta. Cient. Fac. Ci. Letr. Votuporanga 1: 99-122.

Chant, D. A., and E. Yoshida-Shaul. 1991. Adult ventral setal patterns in the family Phytoseiidae (Acari: Gamasina). Int. J. Acarol. 17: 187-199.

Chant, D. A., and E. Yoshida-Shaul. 1984. A world review of four species groups in the genus Typhlodromus Scheuten (Acari: Phytoseiidae): brevicollis, luculentis, carinulatus, and pinnatus. Can. J. Zool. 62: 2631-2642.

Chant, D. A., and J. A. McMurtry. 1994. A review of the subfamilies Phytoseiinae and Typhlodrominae (Acari: Phytoseiidae). Int. J. Acarol. 20: 223-310.

DeLeon, D. 1959. The genus Typhlodromus in Mexico (Acarina: Phytoseiidae). Fla. Entomol. 42: 123-129.

de Moraes, G. J., J. A. McMurtry, and C. A. Campos. 2004. A revised catalog of the mite family Phytoseiidae. Zootaxa 434: 1-494.

Hoy, M. A. 1985. Recent advances in genetic improvement of the Phytoseiidae. Annu. Rev. Entomol. 30: 345-370.

Muma, M. H., and H. A. Denmark. 1962. Intraspecific variation in Phytoseiidae (Acarina: Mesostigmata). Fla. Entomol. 45: 57-64.

Rowell, H. J., D. A. Chant, and R.I.C. Hanssel. 1978. The determination of setal homologies and setal patterns on the dorsal shield in the family Phytoseiidae (Acarina: Mesostigmata). Can. Entomol. 110: 859-876.

Schuster, R. O., and A. E. Pritchard. 1963. Phytoseiid mites of California, Hilgardia 34: 191-285.

Tuttle, D. M., and M. H. Muma. 1973. Phytoseiidae (Acarina: Mesostigmata) inhabiting agricultural and other plants in Arizona. Agric. Exp. St., Univ. Arizona, Tucson, Tech. Bull. 208: 1-55.

Received 9 November 2007; accepted 25 April 2008. 